\author{
Katarzyna Kowalska \\ Uniwersytet Łódzki \\ Wydział Nauk Geograficznych \\ kasiakowalska1386@gmail.com
}

\title{
AN ATTEMPT AT AN INTEGRATED ASSESSMENT OF THE TOURISM ATTRACTIVENESS OF A REGION: THE EXAMPLE OF NORTH KARELIA (FINLAND)
}

\begin{abstract}
The article presents a proposal for an integrated assessment of the tourism attractiveness of a region. The holistic approach used in the author's master's thesis is given as an example. The article presents the results of a survey and 'point bonitation' (a ranking method) for the North Karelia region. In the summary, there is an attempt to assess the methods which were applied in the research.
\end{abstract}

Key words: tourism attractiveness, 'point bonitation', methods of assessment of tourism attractiveness, integrated assessment of tourism attractiveness, North Karelia (Finland).

\section{INTRODUCTION}

The geographic environment is characterized by a complicated and heterogeneous structure, therefore we have to attempt to examine it as a system (KOWALSKI 1996). The main point of interest is tourism attractiveness defined by ROGALEWSKI (1977), a very complex and relative term dependent on the mental and physical features of each person.

Despite many years of tourism development, there is still a lack of an integrated measure for describing the level of tourism attractiveness of large spatial units. WARSZYŃSKA \& JACKOWSKI (1978) mention the following elements as the most frequent: tourism value (through 'point bonitation'), tourism infrastructure (an analysis of the number and type of accommodation units), accessibility (the possibility, time and the cost of transport), the size and type of tourism activity (overnights, number of arrivals, number of tourists per night, the seasonal character), the extent and use of the land, the scale of tourism income, occupational structure and employment in the tourism sector, and the length of tourism trails.

\section{METHODS OF TOURISM ATTRACTIVENESS ASSESSMENT}

The first academic attempts at a holistic assessment of the attractiveness of the natural environment for tourism needs were made in the interwar period but it was not until the 1960s that some studies appeared on the tourism attractiveness of regions which took into consideration various criteria and methodological assumptions. Such studies included those by Mileska, Bajcar and Marsz. In 1974 Warszyńska presented the so-called 'model method' which was a crucial moment. Since the 1980 s some attempts to assess the natural environment in a more comprehensive way than before have been made. Likewise in the assessment of regional attractiveness, apart from a description of the region, 'point bonitation' is used which allows an assessment of the tourism attractiveness of a spatial unit in more objective way (KOWALSKI 1996).

Special attention was paid to the 'point bonitation' method which allows classification of different features and links qualitative and quantitative features together. 'Point bonitation' is quite commonly practiced, however in spite of many good points this method also has some drawbacks. First of all, it lacks a uniform system for establishing criteria and a set of values therefore it is impossible to compare the results of several different studies (even for the same area). The final conclusion also depends on the ranges and the criteria which were taken into account (MICHOWIAK 2004, WARSZYŃSKA 1974). The assessment of qualitative features, despite the greatest efforts remains, a subjective opinion. 


\section{A PROPOSAL FOR AN INTEGRATED EVALUATION OF THE TOURISM ATTRACTIVENESS OF A REGION}

The main aim of the research was to find the most objective assessment of the tourism attractiveness of a region illustrated by the example of North Karelia in Finland ${ }^{1}$. To achieve this goal, methods were combined simultaneously to analyze many aspects and to draw the best conclusion. The first element was a survey concerning the perception of the region by Finns and foreigners to demonstrate its subjective reception. The second element was more objective. It consisted of an analysis of the attractions of the region by 'point bonitation', the acquirement of data on the extent of tourism, an examination of the region concerning its tourism and para-tourism infrastructure, analysis of its internal and external accessibility and a description of the literature. All those elements allowed the construction of a series of graphs, tables and maps which make it possible to answer the question: is North Karelia a real tourism region? It is also possible to answer some other questions such as which places are the most attractive to tourists and what activities result from tourism needs. It was important to discover what attracts tourists to the North Karelia region and what discourages them. An important aim was to discover why tourists concentrate in some towns and areas.

On the basis of the analysis and calculations, both the thematic maps and an integrated map were made. On the thematic maps, areas of great natural and anthropogenic interest and the most attractive places, as well as the most accessible zones, were presented. As a consequence of bringing together those thematic maps, an integrated one was drawn which presents the integrated tourism attractiveness of the region. Through the thematic maps, a clear picture of the elements which determine such attractiveness can be gained. The survey allowed the examination of many aspects of the region, for example cultural events. Very interesting results were obtained as a result of undertaking the survey simultaneously among Finnish inhabitants (domestic tourists) and foreigners (foreign tourists).

Two basic elements used for assessing the tourism attractiveness of a region were complemented with some numerical data obtained from various institutions such as the three national parks (data on the extent of tourism), the Finnish Chamber of Tourism, museums and hotels. An analysis of the literature concerning the region was made, direct research was conducted (participant research, and conversations with employees of national parks to personally verify the actual state of the infrastructure and its quality), tourism indices were calculated and the information given on websites was analyzed (hotels, museums and national parks).

\section{THE EXAMPLE OF THE NORTH KARELIA REGION (FINLAND)}

Karelia is a historical region which stretches on both sides of the state border of Finland and Russia (see Fig. 1). The larger Russian part is known as the Republic of Karelia and the small fragment which lies in Finland is called Western Karelia or Finnish Karelia. North Karelia is a part of Finnish Karelia and is 21585 sq. $\mathrm{km}$ in area.

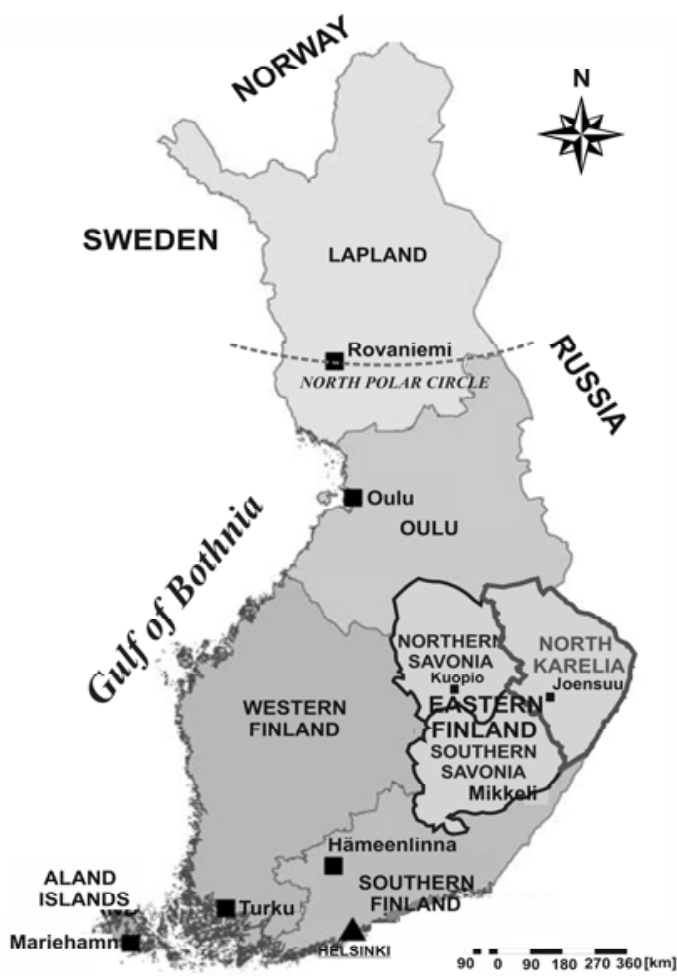

Fig. 1. Location of the North Karelia region on the Finnish administrative map

S o u r c e: author, K. Kowalska, based on a map from d-maps.com; 20.04.2010

North Karelia is divided into 19 smaller units (in Finnish kunta) and has population of about 175000. The capital is Joensuu which has a population of 72791 (in 2010). Additionally, the biggest towns are Lieksa, Kitee, Nurmes and Outukumpu (VUORJOKI \& VIRTAMO 2005; see Fig. 2).

Old traditions, rites and folk customs are still present here and more visible than anywhere else in Finland (LEHTIPUU 1996). Karelia is famous for its cuisine, historical costumes, national views, orthodox churches, chapels, convents, orthodox graveyards, 
language (Karelian dialect), traditions and customs, handicrafts, rites and orthodox holidays, art, and songs (folk songs). It is also the historical birthplace of the 'Kalevala' (RAIVO 2002).

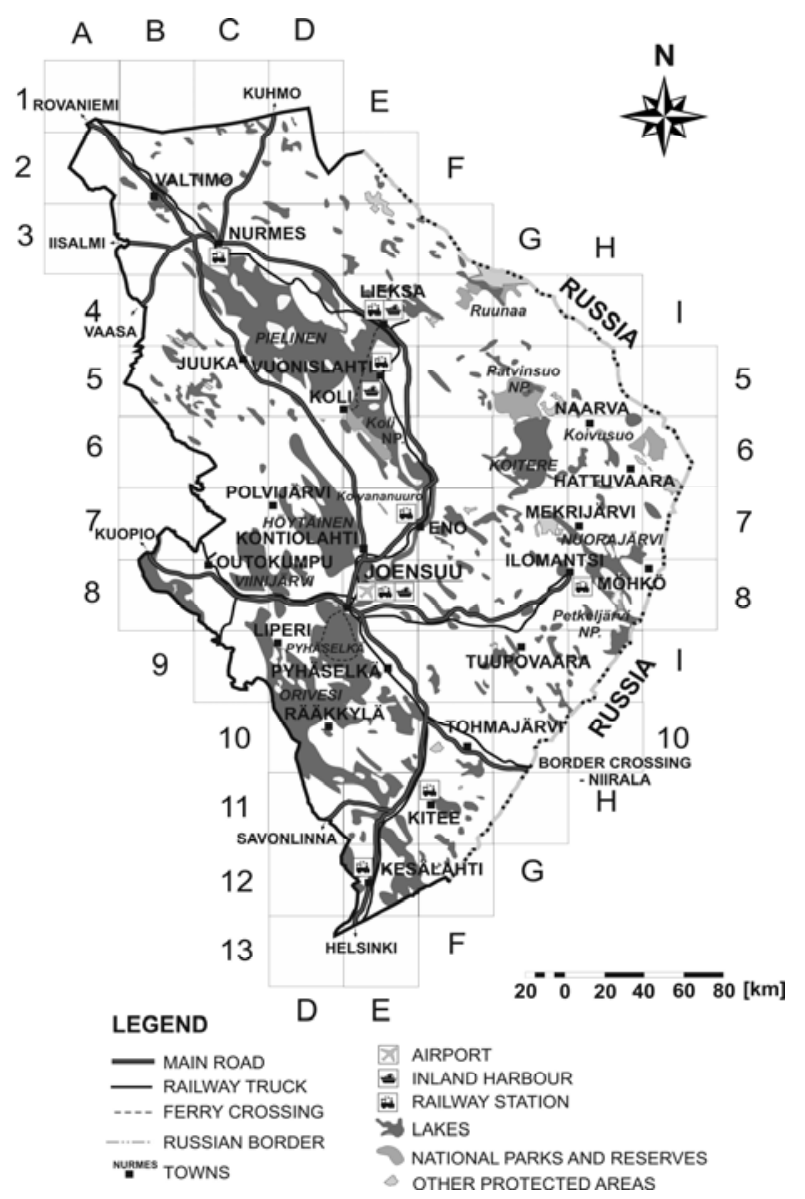

Fig. 2. Road network and the most important towns in North Karelia S o u r c e: author, K. Kowalska, based on the maps Tiekartta 6 (Savonlinna-Joensuu) and 9 (Kuopio-Nurmes), 2007

In order to carry out a 'point bonitation', two topographic maps at a scale of $1: 250000$ was used Tiekartta 6 (Savonlinna-Joensuu) and 9 (Kuopio-Nurmes). The cartographic grid of the map was the base for dividing the region into 74 basic squares each $20 \mathrm{~km} \times 20 \mathrm{~km}$. Each square was ascribed with a number of 'points' which had been calculated before. The criteria which describe the landscape were divided into three groups: natural elements (14), anthropogenic elements (19) and transport accessibility (7; see Table I). As far as natural elements are concerned, each square could achieve a maximum of 35 points, for the anthropogenic elements - 36 points, and for transport accessibility 6 points. In the last group there were two elements for which a negative number of points could be given: the railway (which crosses the square but there is no train station) and an airport (for its noisiness).

The map of natural elements shows that in this regard Karelia is a very attractive region (see Fig. 3).
Very attractive and outstandingly attractive squares cover $70 \%$ of the region (52 squares). Naturally less attractive squares appear only peripherally. The northern part of the research region is more attractive than the southern one.

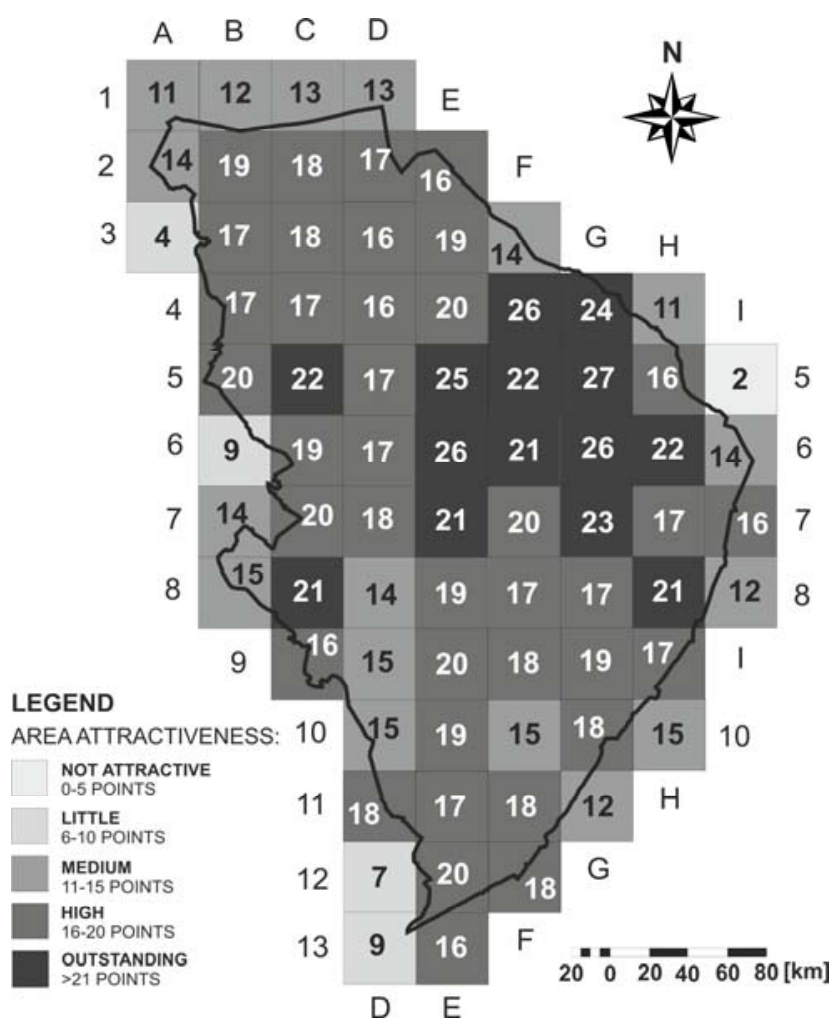

Fig. 3. 'Point bonitation' of natural elements in North Karelia S o u r c e: author, K. Kowalska, based on the maps Tiekartta 6 (Savonlinna-Joensuu) and 9 (Kuopio-Nurmes), 2007

The most attractive squares are at the same time the wildest and most natural where vast areas are under protection. In this part the national parks are located: Koli (E5, E6), Patvinsuo (G5, G6) and Petkeljärvi (H8); the reserves: Kolvanonuuro (E7) and Koivusuo (H6); and also a natural hiking area called Ruuna (F4, G4) (cf. Fig. 2).

The high natural attractiveness of Karelia is due to the fact that this region lies within the biggest European lake district known as the 'Finnish Lakeland'. The lakes are the areas where tourists rest, sunbathe, fish, sail, canoe and swim, and on the rivers canoeing and rafting are organized. The integrated natural value of the region is even greater thanks to vast forest areas which are good places for hiking and forest fruit foraging. The Finnish government and some organizations insist on developing sustainable tourism in Karelia as they understand the importance of the natural elements. Nature is a priceless common treasure which should be available to the future generations. 
$\mathrm{T} a \mathrm{~b}$ l e 1. The number of points given for each element

\begin{tabular}{|c|c|c|c|}
\hline $\begin{array}{l}\text { Group of } \\
\text { elements }\end{array}$ & Sub-group of elements & Elements & $\begin{array}{c}\text { Number of points } \\
\text { available }\end{array}$ \\
\hline \multirow{14}{*}{$\begin{array}{l}\text { Natural } \\
\text { elements }\end{array}$} & \multirow{7}{*}{ Hydrography } & Number of lakes & $0-3$ \\
\hline & & Surface of lakes (\%) & $0-3$ \\
\hline & & Variety of coast line & $0-4$ \\
\hline & & Number of rivers & $0-3$ \\
\hline & & Total length of rivers & $0-3$ \\
\hline & & Surface of marshes (\%) & $0-3$ \\
\hline & & Number of islands on lakes & $0-3$ \\
\hline & \multirow[t]{3}{*}{ Geology and geomorphology } & Number of hills & $0-3$ \\
\hline & & Ravines & $0-1$ \\
\hline & & Mineral deposits, mines & $0-1$ \\
\hline & \multirow[t]{4}{*}{ Forests } & Forest area $(\%)$ & $0-2$ \\
\hline & & National parks (number of them) & $0-2$ \\
\hline & & National park area (\%) & $0-3$ \\
\hline & & Number of reserves & $0-1$ \\
\hline \multicolumn{3}{|c|}{ Maximum points for natural elements } & 35 \\
\hline \multirow{19}{*}{$\begin{array}{l}\text { Anthropogenic } \\
\text { elements }\end{array}$} & \multirow[t]{2}{*}{ Settlement network } & Number of cities and towns & $0-1$ \\
\hline & & Number of villages & $0-2$ \\
\hline & \multirow[t]{9}{*}{ Tourism trails } & Natural trails & $0-2$ \\
\hline & & Number of hiking trails & $0-1$ \\
\hline & & Number of bicycle trails & $0-1$ \\
\hline & & Number of water trails & $0-1$ \\
\hline & & Number of ski trails & $0-1$ \\
\hline & & Total length of hiking trails & $0-3$ \\
\hline & & Total length of bicycle trails & $0-3$ \\
\hline & & Total length of water trails & $0-3$ \\
\hline & & Total length of ski trails & $0-3$ \\
\hline & \multirow[t]{8}{*}{ Tourism infrastructure } & Museums & $0-3$ \\
\hline & & Monuments & $0-1$ \\
\hline & & Bird-observation towers & $0-1$ \\
\hline & & Tourism information centres & $0-1$ \\
\hline & & Hotels & $0-3$ \\
\hline & & Golf course/stables/bathing area & $0-2$ \\
\hline & & Tourist refuge & $0-1$ \\
\hline & & Architectural monuments and others & $0-3$ \\
\hline \multicolumn{3}{|c|}{ Maximum points for anthropogenic elements } & 36 \\
\hline \multirow{7}{*}{$\begin{array}{l}\text { Transport } \\
\text { accessibility }\end{array}$} & \multirow{7}{*}{$\begin{array}{l}\text { Elements of transport } \\
\text { infrastructure }\end{array}$} & Ferry crossing & $0-1$ \\
\hline & & Inland harbour & $0-1$ \\
\hline & & Airport & $-1-0$ \\
\hline & & Train station & $0-1$ \\
\hline & & Railway & $-1-0$ \\
\hline & & Motorway & $0-1$ \\
\hline & & Main road & $0-2$ \\
\hline \multicolumn{3}{|c|}{ Maximum points for transport accessibility } & 6 \\
\hline \multicolumn{3}{|c|}{ Maximum points for all the elements together } & 77 \\
\hline
\end{tabular}

S o u r c e: author, K. Kowalska.

The map of anthropogenic elements is completely different (see Fig. 4). Outstandingly attractive and very attractive areas cover only 14 squares $(19 \%$ of the region) and unattractive or nearly unattractive areas cover as much as $56 \%$ of North Karelia.

The most anthropogenically attractive parts are not as concentrated as the natural ones. The best tourism zone stretches from Joensuu (E8) to Lieksa (E4) and the second smaller zone is in the east and encompasses the area of Ilomantsi, Mekrijärvi and Hattuvaara (H8H6).

A natural convergence in distribution of anthropogenic elements, settlement and transport systems (see Fig. 2) can be observed and the infrastructure that 
makes it possible to make use of what is of natural value (tourism trails, museums, summer cottages, tourism information centres). The most interesting areas are the vicinities of Joensuu (E8), Nurmes (C3), Ilomantsi (H8) and Ruunaa Reserve (F4). The squares where Mekrijärvi (H7), Hattuvaara (H6), Lieksa (E4) and Vuonislahti (E5) are located are also very attractive.

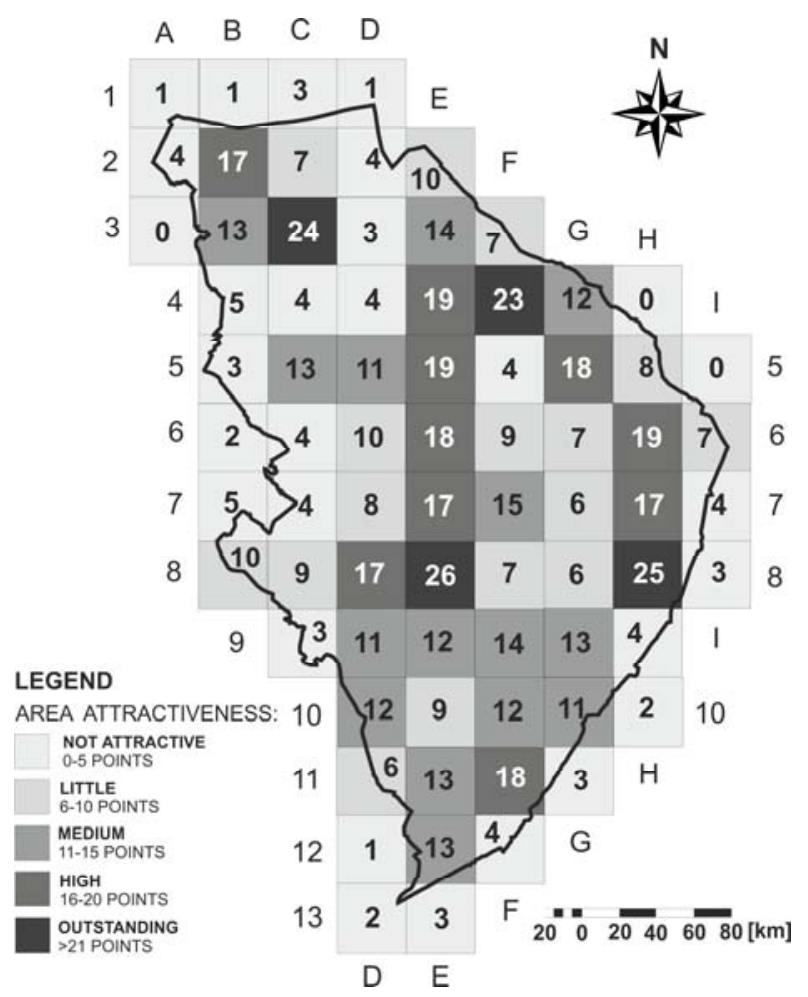

Fig. 4. 'Point bonitation' of anthropogenic elements in North Karelia S o u r c e: author, K. Kowalska, based on the maps Tiekartta 6 (Savonlinna-Joensuu) and 9 (Kuopio-Nurmes), 2007

Thanks to the separate assessment of internal transport accessibility in North Karelia those areas reached easily can be seen (see Figs 2 \& 5).

A central 'vertical' zone (D, E) and a 'horizontal' one (8, Outokumpu-Ilomantsi) can be singled out because the main roads and railway tracks run across these areas. Joensuu has the best connections with the whole region because it has the airport, the main railway and bus stations and is a road hub. According to the map (see Fig. 5) the most difficult for access are small towns which are situated in the western, northwestern and south-western parts of the region.

It should be emphasized that the outstanding, naturally attractive areas (e.g. Ruunaa, Patvinsuo and Koivusuo), which are located in north-eastern Karelia, are difficult to reach. One can reach those places only by track. What is more, the belt which is close to the Russian border is marshy and particularly protected (it is also an external border of the European Union) that is why this zone is hard to reach. The ferry crossing between Koli and Lieksa, available in the summer, is one of the most important transportation facilities (in winter the lake functions as a road for cars).

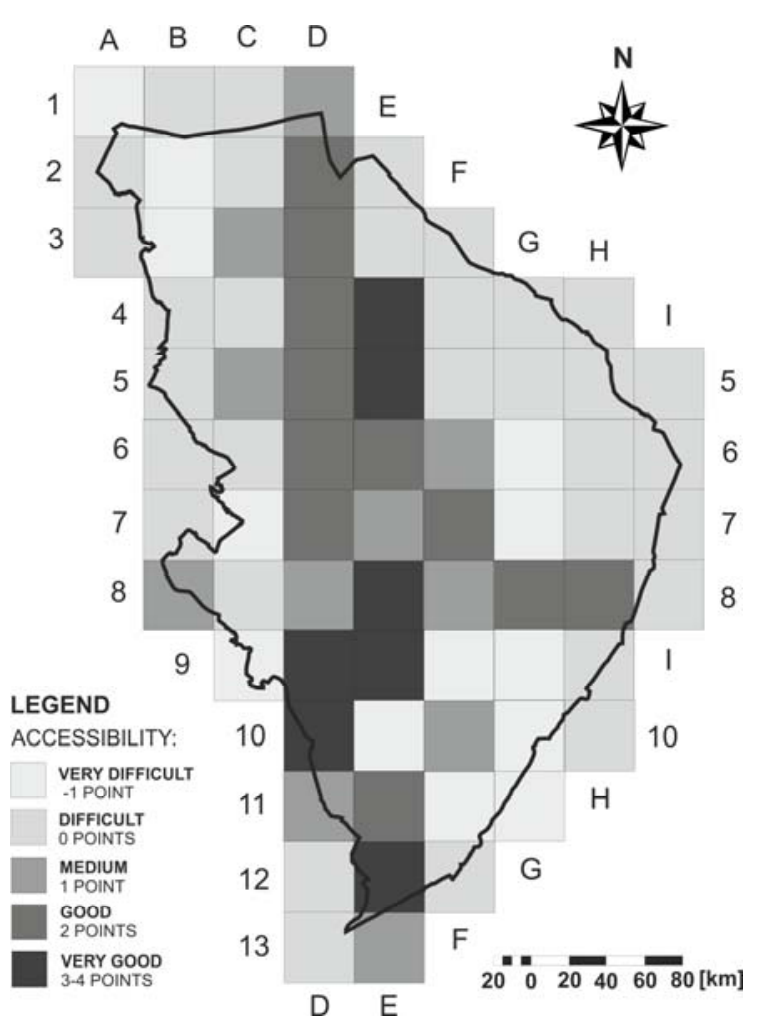

Fig. 5. 'Point bonitation' of transport accessibility in North Karelia S o u r c e: author K. Kowalska, based on the maps Tiekartta 6 (Savonlinna-Joensuu) and 9 (Kuopio-Nurmes), 2007

Owing to the fact that the 'points' for all the elements were summed it was possible to create a general map of North Karelia region (see Fig. 6). It is similar to the map that presents the natural values (in this case).

Outstanding and very attractive squares cover $34 \%$ of the research area meaning that tourism activity is concentrated in one third of the region. The central area, with Joensuu and the north-eastern part where there are the national parks, reserves and other protected areas, is the most attractive. The western part of Karelia is much less attractive.

The second method used in this integrated assessment of tourism attractiveness was a survey on the perception of tourism conducted in the capital of North Karelia, Joensuu. The research lasted between 20th January 2009 and 30th April 2009. The survey, which was conducted in English, was made in two ways - directly (148 respondents) and indirectly via email (52). In total, 200 respondents were interviewed 
including 100 Finns and 100 students who had come to Joensuu from different countries. The research group consisted of 115 women and 85 men. Among the surveyed students were those from 25 different countries, mainly from Poland, Spain, Germany and Czech Republic. All were between 19 and 30 years old - the average age was 23.6.

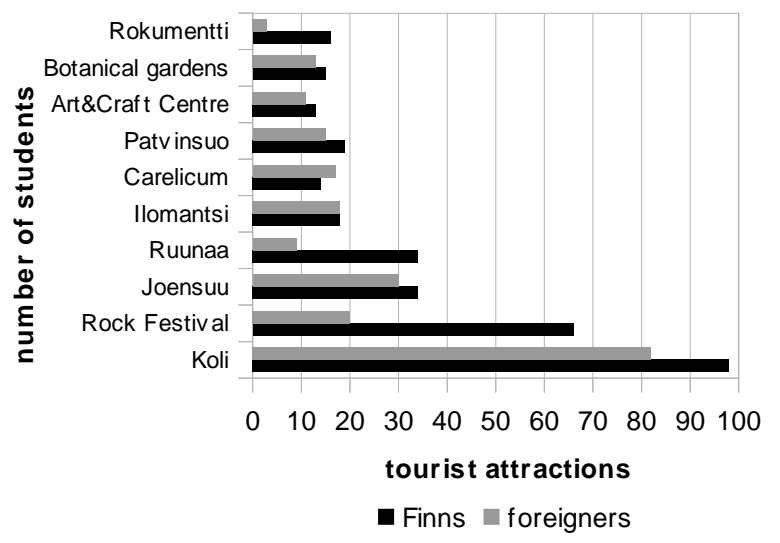

Fig. 6. The biggest tourist attractions in North Karelia region according to Finnish and foreign students S o u r c e: author K. Kowalska

From a tourism point of view, $75 \%$ of Karelia is attractive. The attractiveness of natural elements, towns and cultural events were examined separately and what students find the most attractive (807 points, 180 respondents) is Koli. The Ilosaari Rock Festival received less than half (332 points, 86), while third was Joensuu (186 points, 61). 'Joensuu' means here the both the city with all its attractions and opportunities for recreation. Among the most attractive places in North Karelia students mentioned: Ruuna, Ilomantsi and Patvinsuo. In general, there are seven natural areas, two towns (Joensuu and Ilomantsi), two events (Ilosaari Rock Festival and Rokumentti), and four places in Joensuu: Carelicum, a handicraft centre, inland harbour and the market square. The other important element of the research was the divergence in perception of North Karelia between Finns and foreigners.

Taking into account the specificity of Finland, some extra elements and activities that may enlarge the tourism attractiveness of Karelia were also examined. The most popular are hiking trips. For both groups of students, one of the Karelian attractions is a sauna, with the chance to swim in a lake (in summer) or in a lake 'airhole' (in winter). The sauna is a part of Finnish culture and identity, an inseparable element of everyday life, a remedy for many illnesses and a unique experience. Cross-country skiing is one of the most popular winter attractions while others are swimming in the rivers and lakes in summer and staying in summer cottages. Many people find ice skating a great attraction. Karelia is also known for its local handicrafts (e.g. wire candlesticks), music (folk music from Rääkyla, the works of Sibelius), or local cuisine (e.g. karjalanpiirakka, pulla). Architectural monuments are mainly represented by the old wooden houses (some have been changed into a museum or a shop), Orthodox and Protestant churches. But they are not the most important destinations of trips, because tourism in Karelia concentrates rather on what is of natural value of which ecotourism and active tourism are the most promoted.

The interviewees were also asked to mention some obstacles to exploring Karelia. Both Finnish and foreign students presume that some of the main problems in the tourism exploration of North Karelia are a lack of information about the region, too little promotion and difficult transport accessibility to many places and attractions. High prices are a huge obstacle for foreign students.

At the end of the survey students were asked to put the attractions of North Karelia in order, starting from the greatest in their opinion (see Fig. 7). On the basis of their answers tables and maps of the most attractive places in Karelia were made.

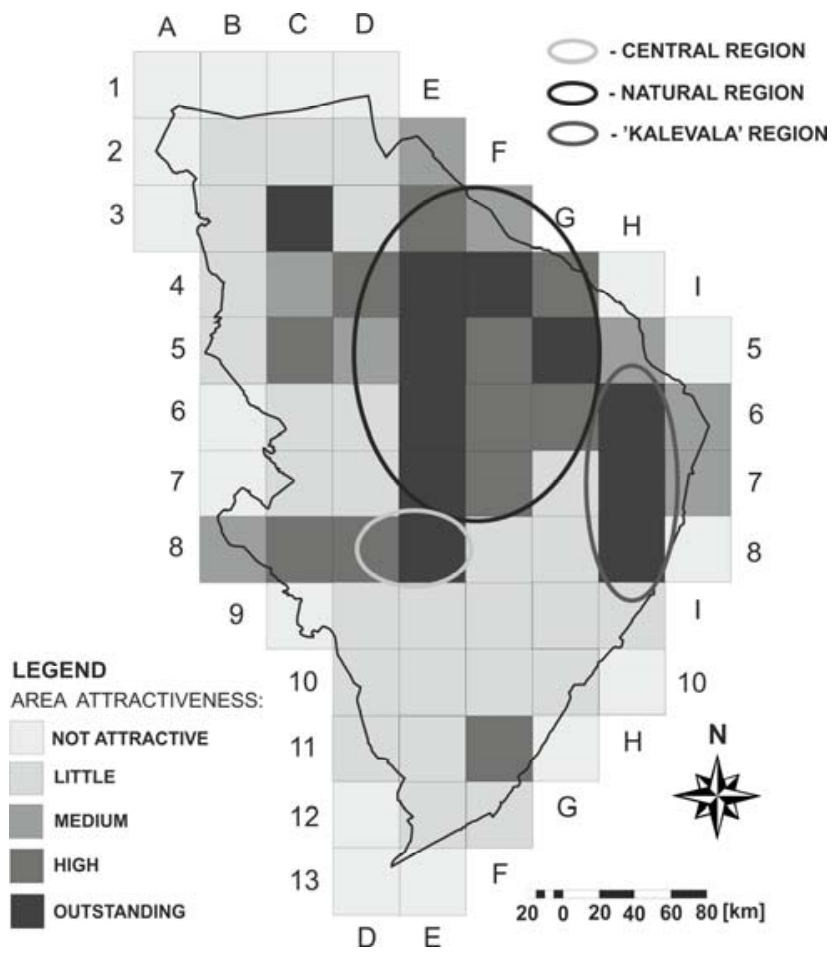

Fig. 7. Compilation of the results of the 'point bonitation' made on the basis of maps and a graphic interpretation of the survey results S o u r c e: author K. Kowalska

Among about $19 \mathrm{mln}$ tourists (domestic and foreign all together; in 2009) who visited Finland, almost 
$0.5 \mathrm{mln}$ go each year to North Karelia (including 50,533 foreigners; see Table 2). The number of Poles visiting North Karelia is about 600 every year. Among all the visitors, domestic tourists dominate with $87.3 \%$ while Russians are the dominant group among foreign tourists $(45.4 \%$ in 2009) - coming to visit their relatives, to look for a job or a better life. More than 1000 in recent years have come from Germany, Holland, Switzerland, Sweden and the United Kingdom. Finns visit North Karelia mostly in summer while in terms of foreign tourists, winter and summer are both popular.

T a b l e 2. Number of foreign tourists who visited North Karelia by country of origin in 2007-9

\begin{tabular}{|l|r|r|r|r|r|r|}
\hline \multirow{2}{*}{$\begin{array}{c}\text { Country } \\
\text { of origin }\end{array}$} & \multicolumn{2}{|c|}{2007} & \multicolumn{2}{c|}{2008} & \multicolumn{2}{c|}{2009} \\
\cline { 2 - 7 } & $\begin{array}{c}\text { no. of } \\
\text { tourists }\end{array}$ & $\begin{array}{c}\text { \% f.t. } \\
1_{\mathrm{a}}\end{array}$ & $\begin{array}{c}\text { no. of } \\
\text { tourists }\end{array}$ & $\begin{array}{c}\text { \% f. } \\
\text { t. }\end{array}$ & $\begin{array}{c}\text { no. of } \\
\text { tourists }\end{array}$ & \% f. t. \\
\hline Australia & 243 & 0.42 & 299 & 0.55 & 138 & 0.27 \\
\hline Canada & 709 & 1.21 & 233 & 0.43 & 224 & 0.44 \\
\hline Czech Republic & 1130 & 1.93 & 571 & 1.05 & 284 & 0.56 \\
\hline Norway & 797 & 1.36 & 339 & 0.62 & 376 & 0.74 \\
\hline Denmark & 623 & 1.06 & 647 & 1.19 & 426 & 0.84 \\
\hline Japan & 848 & 1.45 & 701 & 1.29 & 481 & 0.95 \\
\hline Belgium & 508 & 0.87 & 523 & 0.96 & 496 & 0.98 \\
\hline Poland & 666 & 1.14 & 585 & 1.08 & 525 & 1.04 \\
\hline Spain & 1189 & 2.03 & 123 & 0.23 & 534 & 1.06 \\
\hline USA & 1283 & 2.19 & 857 & 1.58 & 588 & 1.16 \\
\hline Austria & 666 & 1.14 & 477 & 0.88 & 768 & 1.52 \\
\hline Estonia & 1445 & 2.47 & 1332 & 2.45 & 807 & 1.60 \\
\hline Italy & 1564 & 2.67 & 1206 & 2.22 & 819 & 1.62 \\
\hline France & 2538 & 4.34 & 1327 & 2.45 & 992 & 1.96 \\
\hline $\begin{array}{l}\text { United } \\
\text { Kingdom }\end{array}$ & 2471 & 4.22 & 2376 & 4.38 & 1519 & 3.01 \\
\hline Sweden & 2775 & 4.74 & 2310 & 4.26 & 1677 & 3.32 \\
\hline Switzerland & 1895 & 3.24 & 1627 & 3.00 & 1678 & 3.32 \\
\hline Holland & 3498 & 5.98 & 2939 & 5.42 & 1738 & 3.44 \\
\hline Germany & 7636 & 13.05 & 6516 & 12.01 & 5618 & 11.12 \\
\hline Others & 4877 & 8.33 & 4374 & 8.06 & 6634 & 13.13 \\
\hline Russia & 19080 & 32.61 & 23426 & 43.17 & 22940 & 45.40 \\
\hline Total foreigners & 58513 & $12.56 \mathrm{~b}$ & 54270 & $12.61 \mathrm{~b}$ & 50533 & $12.74 \mathrm{~b}$ \\
\hline Finns & 407392 & $87.44 \mathrm{c}$ & 375971 & 87.39 & 345976 & $87.26 \mathrm{c}$ \\
\hline Total number & 465905 & 100.00 & 430241 & 100.00 & 396509 & 100.00 \\
\hline & & & & & & \\
\hline
\end{tabular}

a \% f.t. - percentage foreign tourists (by country), b percentage foreign tourists (relative to domestic), ${ }^{c}$ percentage domestic tourists. S o u r c e: www.stat.fi, Mikko T. Mäkinen.

The urban tourism function index (according to Baretje/Defert) for Joensuu equals 2.61, which according to WARSZYŃSKA \& JACKOWSKI'S (1978) interpretation, means that it is a small administrative centre. The number of tourism accommodation places (per 100 inhabitants) for the whole Karelia region amounts to 3.33. Accommodation available in North Karelia is presented in Table 3.

$\mathrm{T}$ a b l e 3. Accommodation units and tourism beds in North Karelia region: 2009

\begin{tabular}{|l|c|c|}
\hline \multicolumn{1}{|c|}{ Type of accommodation } & $\begin{array}{c}\text { Number of } \\
\text { accommodation } \\
\text { units }\end{array}$ & $\begin{array}{c}\text { Number } \\
\text { of beds }\end{array}$ \\
\hline Hotels & 22 & 2070 \\
\hline Hostels & 5 & 178 \\
\hline Summer houses & 164 & 2666 \\
\hline Other types of accommodation & 26 & 920 \\
\hline Total & 217 & 5834 \\
\hline
\end{tabular}

S o u r c e: author, K. Kowalska, based on information gathered; various sources.

The tourism intensity index according to Schneider is 257.1 in Karelia (tourists plus one-day visitors). The accommodation capacity usage index is 77.13 and the index of development equals 42.85. Accommodation density is low -0.27 available beds $/ \mathrm{km}^{2}$. About $55 \%$ of tourists stay at least one night in Karelia during their visit while the average tourist stays 2.25 days. According to the SWOT analysis and its graphical interpretation in North Karelia is in the 'attack' area (according to STASIAK, WŁODARCZYK \& KACZMAREK 2010). That means that there are great opportunities to use the chief assets. More strengths than weaknesses were noticed and more opportunities than threats (data obtained from the Finnish Central Statistical Office; Mikko T. Mäkinen).

At the end of the research on the most attractive places, the results of the survey were compiled resulting in one common map of tourism attractiveness (Fig. 7). In the last phase the author outlined the three most attractive areas in North Karelia: the Central Region, the 'Natural' Region and the 'Kalevala' Region.

According to the research Finns highly value North Karelia as a tourism reception area yet we cannot talk about its international importance. It is increasingly often visited by foreigners but its peripheral location in Europe means it remains an 'elite' region visited only by very aware tourists.

The development strategies for Finland and North Karelia and government activities show that this region should remain undegraded, that is why they develop sustainable (ecotourism), alternative tourism and agrotourism. In the master's thesis (and briefly in the article) it was shown that North Karelia is a real tourism region. 


\section{SUMMARY OF THE USEFULNESS OF THE RESEARCH METHODS APPLIED IN THE STUDY OF REGIONAL TOURISM ATTRACTIVENESS}

The simultaneous application of two research methods was able to show the most attractive places and areas in North Karelia and present those most eagerly visited. Both methods (the survey and valorization) complement each other and present the tourism attractiveness of this region more completely as well as the location of what is valued within its borders.

The 'point bonitation' method is considered a more objective research method than a survey. However, taking into account that the author was a participant in this case there is an element of subjectivity. In view of the fact that each author may analyze different elements, allocate varying points to each factor and have different ranges, this method is not perfect. Additionally, it makes it impossible to examine such attractions as cultural events.

The other aspect is to select a map at the right scale. It is important to find as precise a map as possible covering many elements, especially tourism ones, and by direct spatial research the author could verify if important elements had not been omitted. To sum up, the 'point bonitation' is a good method to show the more and the less attractive areas but only on the condition that a map is used at the right scale with rich content. Creating thematic maps, showing natural attractiveness, anthropogenic attractiveness and accessibility, allow a perception of which elements contribute to the attractiveness of a region.

The survey conducted among two groups of students revealed which places are most often and most eagerly visited and what the opinions of domestic and international tourists about these places are. In this way which cultural events are attractive, the nature of obstacles according to tourists' experiences and their personal impressions, was demonstrated as well. An analysis of their responses complemented valorization. A combination of the results of both investigations shows objectively that the reception areas are really the most attractive places.
In conclusion, undertaking both analyses simultaneously and combining their results allows assessment of tourism attractiveness in a more objective way and enables conclusions to be drawn. Usage of only one would not reveal answers to all the questions. That is why this is a good way to study various tourism-related aspects within vast spatial units. Yet they still have to be complemented by other indices, statistical data and analysis of the available literature. The approach to assessing tourism attractiveness proposed in the article is vital because it is based on a comparative interpretation which is a valuable source of information and brings together all tourism aspects in a holistic way.

\section{FOOTNOTES}

${ }^{1}$ The method of assessing the region from the tourism point of view proposed in this article was used in a master's thesis entitled 'The Tourism Attractions of North Karelia (Finland)' written by Katarzyna Kowalska at the Institute of Urban Geography and Tourism Studies under Prof. Stanisław Liszewski's direction in 2010 .

\section{BIBLIOGRAPHY}

KOWALSKI R., 1996, Przegląd metod waloryzacji środowiska przy-rodniczego, Folia Turistica, 6, pp. 7-18.

LEHTIPUU M., 1996, Finland a Lonely Planet travel survival kit, Lonely Planet, Finlandia, pp. 354-390.

MiCHOWIAK A., 2004, Waloryzacja turystyczna gminy Dubeninki w świetle różnych metod badawczych, Turyzm, 14/2, pp. 57-71.

RAIVO P.J., 2002, The peculiar touch of the East: reading the postwar landscapes of he Finnish Orthodox Church, Social and Cultural Geography, 3/1, pp. 12-24.

ROGALEWSKI O., 1977, Zagospodarowanie turystyczne, Wydawnictwa Szkolne i Pedagogiczne, Warszawa, pp. 3-24.

STASIAK A., WŁODARCZYK B., KACZMAREK J., 2010, Produkt turystyczny - pomyst, organizacja, zarzadzanie, chapter 2, PWE, Warszawa.

VIRTAMO P., VUORJOKI K., 2005, Outdoor Karelia Finland, PK Media Service Oy, Helsinki.

WARSZYŃSKA J., 1974, Ocena zasobów środowiska naturalnego dla potrzeb turystyki (na przykładzie województwa krakowskiego), Zeszyty Naukowe UJ, Prace Geograficzne, 36, Kraków, pp. 9-17.

WARSZYŃSKA J., JACKOWSKI A., 1978, Podstawy geografii turyzmu, PWN, Warszawa, pp. 20-32. 